\title{
Hubungan Pengetahuan Ibu Pasangan Usia Subur dengan Penggunaan Kontrasepsi IUD di Nagari Andalas Baruh Bukit Kecamatan Sungayang Kabupaten Tanah Datar.
}

lis Rahayu, Mohamad Reza², Elly Usman ${ }^{3}$

\begin{abstract}
Abstrak
Intra Uterine Devices (IUD) merupakan pilihan kontrasepsi yang efektif, aman, dan nyaman bagi wanita. Namun demikian jumlah akseptor kontrasepsi IUD di Nagari Sungayang masih sangat rendah, yaitu 14,97 \%. Tujuan penelitian ini untuk mengetahui Hubungan Pengetahuan dan Sikap lbu Pasangan Usia Subur dengan Penggunaan Kontrasepsi IUD di Nagari Andalas Baruh Bukit Kecamatan Sungayang Kabupaten Tanah Datar. Kontrasepsi adalah cara untuk mengukur jumlah dan jarak anak yang diinginkan. Metode kontrasepsi bekerja dengan dasar mencegah sperma laki-laki mencapai dan membuahi sel telur wanita (fertilisasi), atau mencegah telur yang sudah dibuahi untuk berimplantasi (melekat) dan berkembang dalam rahim. Kontrasepsi yang reversibel adalah metode kontrasepsi yang dapat dihentikan setiap saat tanpa efek lama dalam mengembalikan kesuburan atau kemampuan untuk memiliki anak. Metode penelitian deskriptif corelasi dengan desain cross sectional. Penelitian dilaksanakan di Nagari Andalas Baruh Bukit. Populasi adalah seluruh ibu PUS, sebanyak 788 orang, dan sampel berjumlah 89 orang, dengan pengambilan sampel secara sistematic sampling. Data dikumpulkan melalui wawancara, diolah dan dianalisa secara komputerisasi. Hasil analisa univariat diketahui bahwa $66,3 \%$ responden memiliki pengetahuan tinggi tentang kontrasepsi IUD, (52,8 \%) dan 86,5 \% tidak menggunakan kontrasepsi IUD. Hasil analisa bivariat ada hubungan pengetahuan ibu Pasangan Usia Subur dengan penggunaan kontrasepsi IUD $(p=0,050)$. Dari hasil penelitian ini disimpulkan bahwa ada hubungan sikap ibu dengan penggunaan kontrasepsi IUD.
\end{abstract}

Kata kunci: IUD, Pengetahuan

\section{Abstract}

Intra Uterine Devices (IUD) is a preferred optiuon effective contraceptive, safe, and conveninca for women. However, the number of Intra Uterine Devices (IUD) contraceptive acceptors in Nagari Sungayang is still very low, at $14.97 \%$. The purpose of this study was to determine the relationship between knowledge and attitudes of mothers of fertile age couples with the use of IUD contraception in Nagari Andalas Baruh Bukit, Sungayang District, in Tanah Datar. Contraception is a way to measure the amount of and the distance the child the child of desired. The contraceptive method works by preventing the male sperm from reaching and fertilizing the female egg (fertilization), or preventing the fertilized egg from implanting (sticking) and developing in the womb. Reversible contraception is a contraceptive method that can be stopped at any time without long effects of restoring fertility or the ability to have children. Descriptive correlation method with cross sectional designs. The study was conducted at Andalas Baruh Bukit Nagari. The population is all mothers of fertile age, as many as seven hundreds and eighty-eight people. With a sample of eighty-nine people, with systematic sampling. Data is collected through interviews which are then processed and analyzed by computer. The results of univariate analysis, revealed that $66.3 \%$ of respondents had high knowledge about Intra Uterine Devices (IUD) contraception, (52.8\%) and 86.5\% did not use IUD contraception. The results of the bivariate analysis revealed the relationship between knowledge of mothers of reproductive age couples with IUD contraceptive used $(p=0.050)$. From the results of this study, it was concluded that there was relationship between the attitude of mothers with Intra Uterine Devices (IUD) contraceptive use.

Keywords: IUD, Knowledge 
Affiliasi penulis: 1. Program Studi Magister S2 Biomedik FK UNAND, 2.Bagian Biologi FK UNAND, 3.Bagian Farmakologi FK UNAND Korespondensi: lis Rahayu email: iisrahayu115@gmail.com, Telp: 082287272059

\section{PENDAHULUAN}

Masalah kependudukan merupakan masalah yang dihadapi oleh semua negara termasuk Indonesia. Di Indonesia masalah yang terjadi di bidang kependudukan adalah pertumbuhan penduduk yang masih tinggi. Semakin tingginya pertumbuhan penduduk maka semakin besar usaha yang dilakukan untuk mempertahankan kesejahteraan rakyat. Ancaman terjadinya ledakan penduduk di Indonesia semakin nyata. Indonesia merupakan negara ke 5 di dunia dengan estimasi jumlah penduduk terbanyak yaitu 249 juta. Di antara negara ASEAN, Indonesia dengan luas wilayah terbesar tetap menjadi negara dengan penduduk terbanyak, jauh di atas 9 negara lain. ${ }^{1}$

Salah satu usaha untuk menanggulangi masalah kependudukan tersebut adalah dengan mengikuti program Keluarga Berencana (KB). Program ini dimaksudkan untuk membantu pasangan dan perorangan dalam tujuan kesehatan reproduksi yang berkualitas. Selain itu melalui program ini dapat menurunkan Angka Kematian Ibu (AKI) dan Angka Kematian Bayi (AKB) serta penangulangan masalah kesehatan reproduksi dalam rangka membangun keluarga kecil berkualitas, dan untuk mempersiapkan kehidupan dalam mendukung upaya peningkatan kualitas generasi mendatang. ${ }^{2}$

Kontrasepsi adalah cara untuk mengukur jumlah dan jarak anak yang diinginkan. Metode kontrasepsi bekerja dengan dasar mencegah sperma laki-laki mencapai dan membuahi sel telur wanita (fertilisasi), atau mencegah telur yang sudah dibuahi untuk berimplantasi (melekat) dan berkembang dalam rahim. Kontrasepsi yang reversibel adalah metode kontrasepsi yang dapat dihentikan setiap saat tanpa efek lama dalam mengembalikan kesuburan atau kemampuan untuk memiliki anak. ${ }^{3}$

Beberapa faktor yang mempengaruhi penggunaan kontrasepsi antara lain faktor predisposisi (pengetahuan, sikap, dan unsur-unsur lain yang ada didalam individu), faktor pendukung yaitu tersedianya sarana kesehatan dan faktor penguat seperti informasi oleh petugas lapangan KB dan dukungan suami. Pengetahuan yang dimaksud adalah pengetahuan ibu tentang penggunaan kontrasepsi terutama manfaatnya dalam mencegah kehamilan. ${ }^{4}$

Pengetahuan memiliki hubungan yang signifikan dengan penggunaan alat kontrasepsi, semakin baik pengetahuan seseorang tentang kontrasepsi semakin rasional dalam menggunakan alat kontrasepsi. Selain itu tingginya tingkat pendidikan seseorang juga akan mendukung mempercepat penerimaan informasi KB pada pasangan usia subur. Informasi yang baik dari petugas membantu klien dalam memilih dan menentukan jenis kontrasepsi yang dipakai. Informasi yang baik akan memberikan kepuasan klien yang berdampak pada penggunaan kontrasepsi yang lebih lama sehingga membantu keberhasilan KB. Selain itu, dukungan suami juga mempengaruhi penggunaan kontrasepsi. Klien yang diberikan dukungan oleh suami akan menggunakan kontrasepsi secara terus menerus sedangkan yang tidak mendapat dukungan suami akan sedikit menggunakan kontrasepsi. 5,6,7

Peserta KB baru di Sumatera Barat tercatat sebanyak 140.549 orang $(19,4 \%)$ dengan total peserta KB aktif sebanyak 575.859 orang (79,6 \%) dari 723.538 jumlah PUS. Akseptor KB tersebut terdiri dari IUD $(9,36 \%), \operatorname{MOW}(1,91 \%)$, MOP $(0,17 \%)$, kondom $(6,67 \%)$, implant $(11,35 \%)$, suntik $(50,65 \%)$, dan pil $(19,89 \%) .{ }^{8}$ Berdasarkan profil kesehatan Sumatera Barat tahun 2012, diantara 19 Kabupaten/Kota yang terdapat di Propinsi Sumatera Barat, jumlah akseptor IUD terbanyak terdapat di Kabupaten Tanah Datar yaitu sebanyak 46,5 \% dari 1.766 akseptor KB baru. ${ }^{9}$

Akseptor kontrasepsi IUD di Kabupaten Tanah Datar tersebar di 14 kecamatan. Diantara 14 kecamatan tersebut, jumlah akseptor kontrasepsi IUD di Kecamatan Sungayang berada pada urutan kelima terendah. Secara keseluruhan jumlah akseptor KB di Kecamatan Sungayang yaitu sebanyak 2.025 akseptor (79,8\%) dari 2.539 PUS, yang terdiri dari IUD (23,9 $\%)$, MOP $(0,1 \%), \operatorname{MOW}(3,9 \%)$, Implan $(20,7) \%$, suntik $(40,5 \%)$, Pil KB (7,3 \%), kondom (3,7\%). Kecamatan Sungayang terdiri dari 5 Nagari dengan jumlah akseptor KB IUD terendah terdapat di Nagari Andalas Baruh Bukit dengan jumlah akseptor 118 orang (14,97 $\%)$ dari 788 PUS. ${ }^{10}$ 


\section{METODE}

Penelitian ini adalah penelitian dekriptif corelasi dengan desain cross sectional. Yang dilakukan di Nagari Andalas Baruh Bukit Kecamatan Sungayang Kabupaten Tanah Datar. Sampel yang digunakan adalah sebanyak 89 orang yang memenuhi kriteria inklusi dan tidak memiliki kriteria ekslusi. Sampe ditentukan dengan sistematic random sampling. Data dikumpulkan melalui wawancara terpimpin dengan panduan kuesioner. Data yang diperoleh dilakukan pengolahan secara SPSS dengan menggunakan uji statistik chi- square dengan tingkat kemaknaan $p=0,05$.

\section{HASIL}

Tabel 1. Distribusi Frekuensi Pengetahuan lbu Pasangan Subur tentang Kontrasepsi IUD di Nagari Andalas Baruh Bukit Kecamatan Sungayang Kabupaten Tanah Datar

\begin{tabular}{llcc}
\hline No & Pengetahuan & $\mathrm{F}$ & $\%$ \\
\hline 1. & Tinggi & 59 & 66,3 \\
2. & Rendah & 30 & 33,7 \\
& Jumlah & 89 & 100 \\
\hline
\end{tabular}

Pada tabel 1 dapat dilihat bahwa lebih dari setengah responden $(63,3 \%)$ memiliki pengetahuan tinggi tentang Kontrasepsi IUD.

Tabel 2. Distribusi Frekuensi Penggunaan Kontrasepsi IUD di Nagari Andalas Baruh Bukit Kecamatan Sungayang Kabupaten Tanah Datar

\begin{tabular}{llcc}
\hline No & \multicolumn{1}{c}{$\begin{array}{c}\text { Penggunaan } \\
\text { Kontrasepsi IUD }\end{array}$} & F & $\%$ \\
\hline 1. & Ya & 12 & 13,5 \\
2. & Tidak & 77 & 86,5 \\
& Jumlah & 89 & 100 \\
\hline
\end{tabular}

Pada tabel 2 diketahui bahwa sebagian besar responden tidak menggunakan kontrasepsi IUD yaitu sebanyak 77 orang responden (86,5\%).

Berdasarkan Tabel 3 dapat dilihat hasil dari uji statistik Chi- Square dapat disimpulkan bahwa ada hubungan pengetahuan lbu Pasangan Usia Subur dengan Penggunaan Kontrasepsi IUD di Nagari Andalas Baruh Bukit Kecamatan Sungayang Kabupaten Tanah Datar dimana nilai $p$ value $=0,050$ $(p \leq 0,050)$.

Tabel 3. Uji Statistik Chi- Square Test Terhadap Hubungan Pengetahuan Ibu Pasangan Usia Subur dengan Penggunaan Kontrasepsi IUD di Nagari
Andalas Baruh Bukit Kecamatan Sungayang

Kabupaten Tanah Datar

\begin{tabular}{|c|c|c|c|c|c|c|c|}
\hline \multirow{3}{*}{ 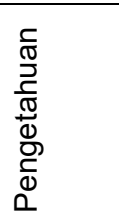 } & \multicolumn{4}{|c|}{$\begin{array}{l}\text { Penggunaan } \\
\text { Kontrasepsi IUD }\end{array}$} & \multirow{2}{*}{\multicolumn{2}{|c|}{ Jumlah }} & \multirow[t]{3}{*}{$\begin{array}{l}\mathrm{P} \\
\text { value }\end{array}$} \\
\hline & \multicolumn{2}{|c|}{$\mathrm{Ya}$} & \multicolumn{2}{|c|}{ Tidak } & & & \\
\hline & $f$ & $\%$ & $f$ & $\%$ & $f$ & $\%$ & \\
\hline Tinggi & 11 & 18,6 & 48 & 81,4 & 59 & 100 & 0,05 \\
\hline Rendah & 1 & & 29 & 96,7 & 30 & 100 & \\
\hline Total & 12 & & 77 & & 89 & & \\
\hline
\end{tabular}

\section{PEMBAHASAN}

Hasil penelitian ini menunjukkan bahwa dari 59 responden yang memiliki pemgatahuan tinggi, terdapat 11 responden (18,6\%) menggunakan kontrasepsi IUD. Sementara itu dari 30 responden yang memiliki pengetahuan rendah , terdapat 29 responden $(96,7 \%)$ tidak menggunakan kontrasepsi IUD.

Uji statistic Chi-Square didapatkan hasil bahwa adanya hubungan pengetahuan Ibu Pasangan Usia subur dengan Penggunaan Kontrasepsi IUD di Nagari Andalas Baruh Bukit Kecamatan Sungayang Kabupaten Tanah Datar dimana nilai $p=0,050$ $(p \leq 0,050)$.

Prilaku seseorang dipengaruhi oleh pengetahuan, sikap, kepercayaan, tradisi dan sebagainya. Namun dari semua itu pengetahuan memegang peranan penting karena jika seseorang mengetahui dan memahami sesuatu, maka ia bisa mengambil sikap dan bertindak sesuai dengan apa yang diketahuinya. Perilaku seseorang dipengaruhi oleh sikap dan tindakan. Jika seseorang mengetahui dan memahami suatu maka ia bisa mengambil sikap dan tindakan sesuai dengan apa yang diketahuinya. ${ }^{4}$

Hasil penelitian ini sejalan dengan penelitian sebelumnya tentang Hubungan Baberapa Faktor Pada Wanita PUS dengan Keikutsertaan KB Di Desa Duren Kecamatan Sumowono Kabupaten Semarang yang hasil nya menunjukkan bahwa ada hubungan faktor Pengetahuan dengan Keikutsertaan KB pada Ibu PUS. ${ }^{11}$

\section{SIMPULAN}

Ibu Pasangan Usia Subur yang memiliki pengatahuan rendah cendrung tidak menggunakan kontrasepsi IUD, dengan demikian diharapkan kepada tenaga kesehatan untuk dapat melakukan penyuluhan ataupun memberikan pendidikan kontrasepsi kepada 
Ibu PUS dengan mengikut sertakan KADER maupun tokoh masyarakat yang ada di daerah tersebut. Dengan begitu diharapkan angka penggunaan kontrasepsi dapat meningkat.

\section{UCAPAN TERIMA KASIH}

Penulis mengucapkan terima kasih Kepada BKKBN Kabupaten Tanah Datar yang bersedia memberikan informasi yang dibutuhkan selama penelitian berlangsung, serta KADER yang membantu peneliti untuk dapat melakukan wawancara kepada responden.

\section{DAFTAR PUSTAKA}

1. Kemenkes RI. Riset Kesehatan Dasar, RISKESDAS. Jakarta. Balitbang Kemenkes RI. 2013. Hal 13-14.

2. Bappeda. Kependudukan dan Keluarga Berencana (KB). Diakses dari http://www. Bappenas. Go.id tanggal 27 agustus 2017.

3. Sulistyawati A. Pelayanan Keluarga Berencana. Jakarta. Salemba Media. 2011. Hal 5-7.

4. Notoatmodjo S. IImu Kesehatan Masyarakat. Jakarta. Rineka Cipta. 2007. Hal 7-8.

5. Arliana WOD, Sarake M, Seweng A. Faktor yang Berhubungan dengan Penggunaan Metode Kontrasepsi hormonal pada Akseptor KB di Kelurahan pasarwajo Kecamatan Pasarwajo Kabupaten Buton Sulawesih Tenggara. Universitas Hasanudin. Makasar. 2013. Di unduh tanggal $\quad 12 \quad$ Maret 2017 http://repository.unhas.ac.id/bitstream/handle/123 456789/6598/Jurnal_WaOde\%20Dita\%20Arliana_ K11109012.pdf?sequence=1.

6. Handayani S. Buku Ajar Keluarga Berencana. Yogyakarta: Pustaka Rihama. 2012. Hal 17.

7. Arum, Dyah N. Panduan Lengkap KB terkini. Mitra Cendekia Offset. Jogjakarta. 2008. Hal 3-4.

8. BKKBN. Hasil Pelaksanaan Sub Sistem Pencatatan dan Pelaporan Pelayanan Kontrasepsi Februari 2013. Tahun 2013. Hal 7-13.

9. Dinas Kesehatan Sumatera Barat.Profil Kesehatan Sumatera Barat. 2014. Hal 25-26.

10. BKKBN Kabupaten Tanah Datar. Laporan Akseptor KB. 2014. Hal 2-3.

11. Adiputra R, Nugroho D, Winarni S, Dharminto. Hubungan Beberapa Faktor pada Wanita PUS dengan Keiskutsertaan KB di Desa Duren Kecamatan Sumowono Kbupaten Semarang. Jurnal Kesehatan Masyarakat Universitas Diponegoro Semarang. 2016. Diunduh tanggal 18 Februari $2017 . \quad$ http: I/ejournal-S1. Undip.ac.id/index. Php/ jkm. 